\title{
Re-Inventing Teachers' Competences at Early Childhood Education in Building Characters Needed for Global Competition
}

\author{
Karmila Machmud \\ Universitas Negeri Gorontalo \\ karmila36@gmail.com
}

\begin{abstract}
The goal of this paper is to elaborate and to re-invent the competencies needed by early childhood education teachers. Building children's character from an early age is significant, but the main problem that is often overlooked is the contribution of Early Childhood Education teachers. Children's character formation is largely determined by the quality of early childhood teachers. So if we want to instill character values required by our nations, the improvement of the quality of early childhood teachers is very significant. In terms of shaping children's character, they should be equipped with some important skills and competences, because they have a significant role in building the Indonesian Children's characters needed in global competition without abandoning their identity as a dignified Indonesian.

Tulisan ini bertujuan untuk menjelaskan dan menemukan kembali kompetensi yang harus dimiliki oleh guru PAUD. Pembentukan karakter anak usia dini sangat ditentukan dengan kualitas guru PAUD. Sehingga jika kita ingin menanamkan nilainilaikarakter yang dibutuhkan oleh anak bangsa kita, maka peningkatan kualitas guru PAUD sangatlah signifikan. Dalam hal pembentukan karakteranak, seorang guru PAUD harus dibekali dengan beberapa keahlian dan kompetensi, karena mereka bertanggung jawab untuk membentuk generasi Indonesia yang mampu berkarya di tingkat Internasional, tanpa meninggalkan identitasnya sebagai bangsa Indonesia yang bermartabat.
\end{abstract}

Keywords : Building Character; Early Childhood Education; Global competition 


\section{A. Introduction}

Early childhood character building is largely determined by the quality of early childhood education teachers. Children in Indonesia at early ages mostly believe their teacher more than their parents. This notion inspired me to write this article. I have found myself struggling to make my six year old daughter believed me when I helped her working on her English homework; she was refusing my suggestion and told me that it was not what her teacher told her. I was irritated at the beginning, because what the teacher said to my daughter was something wrong and I needed to correct it, but this experience was like a wake-up call to me that the role of early education teachers is more than important in forming our children's characters. What if they teach something wrong? What if they show a wrong attitude? What if they have a habit of saying curse words in front of our children? This might sound too paranoid, but as a parent, having this worry feeling is inevitable.

Another notion that inspired me to write this article is my interest in the problems associated with early childhood education. It was all began when I got a chance to study in Australia and the United States. From both social and academic interactions, I have learned that people in developed countries appreciate and respect their children more. In the United States of America, children is considered and treated as a first class citizen (the primary citizens). Children are given the best education, nutrition and health care in the country. For example, to provide adequate nutrition to children, the government initiate a WIC program (Woman and Infant Care program) through this program, the children from low income citizens are given subsidized food and beverages for free every month, it consist of 4 gallons of milk, 2 cartons of cereal, two loaf of bread, one jar of peanut butter, 2 bottles/cartons of fruit juice, a dozen eggs and the amount $\$ 6$ to buy fresh vegetables from the local farmer's market. In educational services, children from low income family are attending a free school like Head Start, this kind of early childhood education programs are provided free of charge. In Head Start children are given free nutritious breakfast and lunch, and free transportation. For health care, every 6 months, children who attend Head Start are given physical examinations and dental health services for free since these are the main requirements for attending school. For children who require further dental care is subsidized $\$ 65$ from the school.

This paper discusses the needs for re-inventing the competences of teachers who teach in early childhood education institutions. The 

for Global Competition

discussion is started with the lesson learned from developed countries about the way they treat their children, and then followed by the arguments about the significance roles of early childhood education teachers. This paper also explains what constitutes early childhood education and what should be done in order to improve the quality of the early childhood education in Indonesia.

\section{B. The Lesson Learn from Treating Children in Developed Countries}

The early childhood education in developed countries impressed me in many ways. Children are given the highest appreciation as individuals who have their own responsibility and their own way of thinking. Children are not overly dictated and they have almost never been blamed by their parents, teachers, and even the society surrounding them. Through this experience and a quite long process of thinking, I concluded that the educational process, the approach taken, as well as the respect for a child as an individual are basic ingredients in forming of individual with strong character who is able to bring his country into a developed country and to be strong in the competition of global society.

Let me share some of the experience I have been through with regard to the character of children of early age. Indonesian Students Union was once given the opportunity to introduce angklung (a traditional musical instrument from west Java) to children aged 3 weeks to 5 years old at Ohio University Child Development Center, USA. At that time, I have witnessed how enthusiastic the children to raise their hands when given the opportunity to ask questions, all of them wanted to ask. This is contradicted with the atmosphere of kindergarten in Indonesia, when given the opportunity, the children rarely ask questions. This situation is also applicable to students up to the level of higher education. The students are mostly silent and rarely want to participate in class discussions or just to ask questions.

The same problem is also experienced by the majority of Indonesian students who are studying abroad; they find it difficult to participate in class discussions. This is due to the fact that the learning process that the children have experienced in Indonesia, and in Asian countries in general, mostly do not give a chance to children to give their opinion freely. Most of our teachers tend to not like students who ask too much questions or too often express their opinion. 
On another occasion, the Saman Team Permias (Indonesian Students Association USA) Ohio University was invited to East Elementary Athens Ohio International week. The program was designed to expose the children to cultural performances from different countries. At the same time the students are also given a chance to show their skill in front of their parents, family, and friends. Then there was a child aged about 9 years old playing an electric guitar with a tone that is chaotic even tends to deafening. However, when he finished playing the guitar, everyone stood up and applauded him. It was an eye opening on how people respect their children's creativity, no matter how horrible it was, because if that kid performed in Indonesia, he would have been asked to come down from the stage. From this occasion I learned to reward children who dare to take the stage and perform, albeit with modest talent, it is important to establish the courage of a child to appear and being a stand out.

\section{The Significance Role of Early Childhood Education Teachers}

In Indonesia, in general, and specifically in my place, it is not uncommon to laugh at children who are not performing perfectly. This taught us not to speak, to perform, not to mention to stand out if it is not something that socially-accepted level of ideas or performances. People are, in general do not understand the damage they made to the children's motivation to speak up or to stand out. Our children are too afraid to be insulted by their friends and even by their teachers. Our children do not dare to appear and to compete.

I was so blessed to be given the opportunity to work at Ohio University Child Development Center for about one year. I worked as a graduate assistant of the director of CDC. During that time, I learned a lot of how the teachers give their attention, treat their children, and educate them. I have also learned the process of recruitment of the master teachers who will work there.

To be accepted as a master teacher at the early childhood level is not easy, because the undergraduate bachelor degree is not the only requirement. An early childhood teachers must have some other essential requirements. Besides holding a degree in early childhood education, a master teacher candidate must have a certificate as a first aid program participant in accidents and disasters; this includes a skill of providing CPR for children. This shows that the students' safety at school is the teachers' responsibility. 

for Global Competition

A prospective early childhood teacher in the USA must go through several stages to test their competence before being recruited as a master teacher in any early childhood education schools or centers. This confirms that the recruitment process of early childhood education teacher in the USA is significant.

To sum up, children in the United States and other developed countries are treated equally and appreciated as an individual figure. "They are not mini us, they have their own mind, their own thinking".' Children have a desire and a mind of their own, so it is wrong if many parents impose what their children think should be similar to what they think.

Based on the explanation above, I was challenged to conduct research on early childhood education in Indonesia. Because a children's personality and character will be formed properly by teacher who has good personality and has high competences. Those competences will be discussed in the following section on this article.

\section{Defining Early Childhood Education}

The National Association of Early Years Children (NAEYC) defines early childhood as children who are in the age range of 0 to 8 years. In Indonesia alone, the definition of early childhood is included in Law No. 20 Year 2003 on National Education System Article 28 paragraph 1 reads "Early Childhood Education organized for children from birth to six years and is not a prerequisite for basic education"

An educational philosophy expert such as Montessori believes that 0-6 years is the golden age, the golden age of a child where the intellectual and emotional intelligence are formed. Internationally, plenty of evidences indicate that early childhood education have a positive effect on children's cognitive and social development, and refining their education process. ${ }^{2}$

There has been a strong consensus that character education should start early age children, because at an early age, children develop values, attitudes, skills, traits, and habits that will last a long time. Early childhood education is a process of education to lay a solid foundation for the development of the intellectual, psychological, emotional, social,

\footnotetext{
${ }^{1}$ Waller, C. Personal Communication. Athens: Ohio University, 2011.

2 Lynch, R. G. Early childhood investments yields big payoff (Policy Perspectives). San Francisco: WestED, 2005
} 
and physical for lifelong learning. ${ }^{3}$ Therefore, early childhood education has a very strong potential in growing values, attitudes, skills and habits that will support the character building.

Shaping the character of the Indonesian people is the responsibility of all parties, but the most powerful influence is the role of parents and teachers. Thus, the attention to the importance of early childhood education is very important because the neglecting towards the quality of early childhood education would significantly affect the formation of the Indonesian community in subsequent years.

\section{E. The Characters of People in Global Society}

A global community competition in the year of 2045 needs a strong human character who is able to stand out and cannot be displaced by the swift of current global developments. ${ }^{4}$ suggests that the dimensional characteristics of human beings in the global era is required to have the following capabilities: (1) critical thinking, sensitivity, independent, and responsible, (2) to work as a team, good personality, and open to changes, and high work performance, and (3) think globally in solving local problems, and has a high emulation. In line with Mukhadis, Ary Gina Agustian ${ }^{5}$ concluded that the CEO (Chief Executive Officer) or leaders of top corporates or organizations of the world can successfully reach the peak of his career and remain at the peak of his career over the years because of the strength of character they have. Character includes honest, able to look forward, competent, inspiring, diligent, fair, broad-minded, firm, unflinching co-operation, imaginative, ambitious, courageous, caring, mature, faithful, self-control, and independent.

Based on the above explanation and on my own experience mingled with the global community, it can be concluded that the characters needed by Indonesian people to be able to live and compete in a global society are as follows:

Appreciate the difference. To be able to compete globally, the Indonesian people have to realize that the global community is extremely

${ }^{3}$ Samuelsson, I. P and Kaga, Y. The contribution of early childhood education in sustainable development. Paris: UNESCO, 2008

4 Wagiran. Peran guru dalam mengembangkan karakter pada pendidikan kejuruan di era global. Makalah. 2011

${ }^{5}$ Ibid 

for Global Competition

diverse. They come from different countries with different races and cultural backgrounds. The ability to appreciate the differences is needed to be able to live and compete in the global competition. Have respect for fellow human being regardless of racial background, culture, religion, and language is important to prevent conflicts that invariably arise due to misunderstanding.

Ability and willingness to compete (Competitive). Global community life, which is full of competition, requires human characters that are able and willing to compete.

Not easily give up (Determined). A-not easily-give up character is largely determining the success of the Indonesian people in the global competition. To be the last man / woman standing requires persistence and the ability to not give up to keep trying to improve and refine everything we do.

Eloquent. The mastery of foreign languages used in global community is needed in communicating the success of the global society in the $21 \mathrm{st}$ century; however, the mastery of language is not the only determinant factor of success. Speaking skills, communication skills, the use of the rhetoric is an important factor that is needed on the association and competition in the global community. Experience has shown that speaking skill tends to push the success of a leader.

Open to change (Open-minded). The character figure that is able to accept the changes tend to be able to survive in the global flow. Given the fact that change is definite, those who oppose the change will not last and tend to lose in global competition.

Creative thinking. Creativity is an absolute character of the Indonesian people to be able to live and compete in the global era. Creativity will emerge from the creative thinking and the ability to think ahead.

Appreciate cleanliness and health. Global society is those who appreciate cleanliness. For most of people living in developed countries, hygiene and health are their priority. The cleanliness of the surrounding environment is a shared responsibility, not just personal responsibility alone.

Respect the environment. Indonesian should realize that we are part of the world. Thus preserving the environment is a shared responsibility. We must realize that our world is getting older, so the human characters that respect environment are needed to preserve our earth. Given the importance of the formation of human character who is able to appreciate environmental preservation, UNESCO has repeatedly carry out 
workshops and conferences to discuss the preservation of the environment as the main topic, of which recommends environmental conservation education from an early age. ${ }^{6}$

All of the above characters are significant for Indonesian people to be able to live, socialize, and compete in the global era. Shaping and forming the character of Indonesian people is the responsibility of all levels of Indonesian society, and it should be started on their early life. Given the urgency of instilling some important characters from an early age, the quality of early childhood education deserves serious attention. Considering that the powerful effect on young children development and character building rely on not only parents, but also teacher, thus, the important factor that must be considered is improving the quality of teacher educators at the Early Childhood Education (ECE). An early childhood teachers must be able to build children characters needed by Indonesian people to be able to live and compete in the global life.

\section{F. Early Childhood Education Teachers' Competences}

Teacher is the closest models that can be examined and copied by the children in the classroom. Therefore, teachers should have the characters which are intended to be built on children in their class. Early childhood teachers must have a good personality because all the words and actions made by early childhood teachers will be a significant contribution to the formation of a child's character and personality.

It sounds very idealistic, but it can be done in several ways, among others are: first, by the improvement of early childhood education curriculum by incorporating all competencies that must be owned by prospective early childhood teachers. Secondly, the improvement of recruitment process of early childhood teachers.

Government Regulation No.19 of 2005 on National Education Standards Chapter IV states that the learning agent's competence in Early Childhood Education includes pedagogical competence, personal competence, professional competence and social competence. ${ }^{7}$ Describes these competencies within the scope of ability expected from early childhood educators. However, some of the capabilities described is still a little abstract to understand. In this paper, I select and add some capabilities that must be possessed by early childhood educators that in

\section{${ }^{6}$ Ibid}

${ }^{7}$ Sujiono, Y. N. Konsep dasar pendidikan anak usia dini. Jakarta: Indeks. 2009 

for Global Competition

turn will enable them to build and shape the Indonesian children characters. These characters will help children to grow up as human who can live, socialize and compete in the global era:

Pedagogical competence includes the ability to:

- understand the characteristics, needs, and child development. Early childhood teachers must completely mastered the various theories of child development to be able to understand the characters, needs and wishes of children.

- respect a child as an individual who has his own thoughts and desires.

- master the concepts, principles and learning strategies. Early childhood learning strategy is very different from adult learning. Teachers should be able to create interactive learning situations, inspiring, fun, challenging, and motivating to stimulate children to actively engage in the learning process.

- provide the best possible opportunities and rewards for children's creativity and independence. Children's courage and desire to excel and to be creative can be stimulated by appreciating and rewarding their works.

- master technology-based learning media. The 21st century generation is the Digital Natives, ${ }^{8}$ referring to the children who were born in the era of rapid technological developments. Digital natives have different needs. They understand technology more and expert users of technology in daily life. Therefore, an early childhood teacher is required to master technology in order to meet the needs of early childhood education at present and in the future.

- master the languages required in the association of the world community.

- have knowledge and awareness of the importance of preserving the environment. It is important that each learning activity can always be directed to the importance of preserving the environment. Children can be taught gardening and how to recycle.

\footnotetext{
${ }^{8}$ Prensky, M. Digital-based game learning. New York: McGraw-Hill, 2001
} 
Personality competence, include the ability to:

- be an honest, mature, dignified, fun, stable, loving children, a wise and prudent, and patience person. Children learn from a model they see every day, they tend to follow what was done and said by the model he saw. Early childhood teachers are the closest models they encounter every day after and their parents and family members. Therefore, early childhood teachers should have a personality mentioned above. A patience to serve the needs of children and to answer the children's questions, also needed by an early childhood teacher.

- have good moral, to inspire and to be a role model for children.

- have a fair and democratic soul, attitude, and behavior. Democratic attitudes, able to be fair and wise is the characters needed by Indonesian people now and in the future; therefore, early childhood teachers should have and show the attitude of democratic, just, and wise to be imitated by children.

Social competence, include the ability to:

- be open, objective and non-discriminatory. Non-discriminatory attitude is needed from an early childhood teacher, because the ability to non-discriminatory demonstrates the ability to appreciate the differences. This is one of the important characters of the Indonesian people in order to compete in the midst of a global community which consists of diverse ethnicity and language.

- use polite language and behavior when communicating and interacting with children and fellow early childhood teachers.

- Actively communicate with the parents of their students on the progress and problems faced by children. Interaction with parents is very important in children's learning process, because the parents are those who understand their children's development; therefore, the information from parents regarding their children is significantly useful for teachers. Cooperation between teachers and children in the process of the character building is very significant.

- actively work with fellow educators. Share knowledge with other early childhood educators will enrich the knowledge needed by a teacher to keep up to date with the recent change surrounding the early childhood education. 

for Global Competition

Professional Competence, include the ability to:

- stimulate children's spirit and motivation to be able to compete in a way that is honest and dignified.

- stimulate children's ability to think critically. Various games and other activities conducted in schools should be able to stimulate the children's ability to think positively.

- link children development theory with everyday life.

- have expertise in providing first aid. Given that teachers are the closest people with children in school, the teacher is the first person who should provide help if a child is sick or experience an accident during the learning process at school.

- integrate technology in the process of communication with parents, and for the development of the profession.

All these competencies should exist in the person who will be recruited as early childhood education teachers. The prospective teachers should be tested before being accepted into an early childhood education center or institution. They should be able to show these competences as a main test and examination for the recruitment.

In the United States, to become a master teacher in early childhood education is not as easy as to be a teacher of early childhood education in Indonesia, a lot of requirements must be submitted. Before a pre-service teacher being promoted to be a master teacher, a candidate must be a professional intern first.

The requirements to become a professional intern is not easy, in addition to his/her undergraduate degree they must also have a federal permit indicating that they had not been involved in any criminal activity. The intern should also provide a reference letters from three people as a guarantee that the person has never been involved in any criminal activity and able to perform duties as a teacher. They also need to show medical certificates stating that they do not have a disease that can be transmitted to children. Besides, they need to have certificate as a trained-person who is able to give first aid such as CPR; and finally, the most important requirement is that a professional intern needs three to six months working with master teacher to demonstrate all the competencies required to be a master teacher before being accepted to work as a teacher at the school. 


\section{G. The Basic Principles of Reggio Emilia Approach in Early Childhood Education}

Principles Reggio Emilia approach is widely used by child development center and has been a constant reference to early childhood education in the United States in general and at Ohio University in particular. Reggio Emilia approach is put forward by Edward, Gandini and Foreman, ${ }^{9}$ in their book titled The Hundred Languages of Children: The Reggio Emilia Approach to Early Childhood Education. This approach has been useful to build children characters and personalities.

The following are the fundamental principles of Reggio Emilia approach as mentioned by Louise Boyd Cadwell $:^{10}$

\section{The child as protagonist / leader.}

An early childhood teachers must understand that children are strong and capable. All children have the preparation, potential, curiosity, and interest in constructing their learning development, and negotiate with whatever brought to their environment. Children, teachers, and parents are three important elements in the education process. ${ }^{11}$

\section{The child as collaborator.}

Education should focus on each child's relationship with other children, families, teachers, and the wider community. So education is not just one isolated child. Early childhood education should be emphasized working in small groups. It is based on social constructivist model that supports the idea that children make up the characters themselves through interaction with their peers, with adults, with the things they find in this world, and the symbols. ${ }^{12}$

\section{Child as a communicator}

This approach fosters intellectual development of children through a systematic focus on specific symbols such as words, gestures, drawings, paintings, buildings, statues, shadow, collage, dramatic play

9 Gandini, L. Fundamentals of the Reggio Approach to Early Childhood Education. Young Children, 49 (1), 1993, 4-8.

Press, 1997

${ }^{10}$ Cadwell, L.B. Bringing Reggio Emilia home. New York: Teachers College

${ }^{11}$ Gandini, L. Fundamentals ..., 4-8

${ }^{12}$ Lewin, A. The Fundamentals of the Reggio Approach. In Cadwell, L. (Ed.). Bringing Reggio Emilia Home. New York: Teachers College Press, 1995 

for Global Competition

and music. ${ }^{13}$ This leads children to the level of communication, symbolic skills, and creativity are surprising Children have the right to use a lot of materials to that they can find and communicate what they know, understand, want to know, ask, feel, and imagine. In this way, they make their thinking process more visible through the natural 'language'.

\section{Environment as a third teacher (Outdoor Education).}

There is order and beauty in design and space organization in schools as well as the equipment and materials in them. ${ }^{14}$ Each corner has its own identity and purpose, and has the potential for each child to participate and to communicate, and it is valued and guarded by children and adults.

\section{Teacher as partner, nurturer and counselors}

Teacher should facilitate the child's exploration of the theme; working on projects that require a short time and a long time, and guide children to experience to find something and solve problems. ${ }^{15}$ To find out how to plan and begin their work, the teacher must listen and observe children closely. Teachers ask, find the idea of children, hypotheses, and theories; and provide opportunities for discovery and learning. ${ }^{16}$

\section{Teacher as researcher.}

Teachers work in pairs and maintain strong relationships with other teachers; they are involved in the discussion and interpretation of their work and children. The process of exchanging ideas could be a training and enrichment theory. The teachers see themselves as researchers preparing documentation of their work with children, which also considered as a researcher.

\section{Documentation as communication.}

Consideration and full attention are given to the presentation of the minds of children and adults who work with them. Teacher comments which aims at the children's learning process, transcripts of verbal language children (e.g., words and dialogue), photographs of their activities, and the representation of their thinking in a variety of media compiled in a book or panel are designed to demonstrate the learning

${ }^{13}$ Edward, C., Gandini, L., and Forman, G. The hundred language of children: The Reggio Emilia approach to early childhood education. USA: Ablex Publishing. 1993

${ }^{14}$ Lewin, A. The Fundamentals of the Reggio Approach. In Cadwell, L. (Ed.). Bringing Reggio Emilia Home. New York: Teachers College Press, 1995

${ }^{15}$ Edward, C., Gandini, L., and Forman, G. The hundred ... 1993

${ }^{16}$ Ibid 
process at school. Documentation can be used for many purposes. Through documentation, parents can understand and know their children experience. Documentation can also make teachers understand their young students better; to evaluate the results of his own work, and to exchange ideas with other educators. The documentation also shows children that their work is appreciated. Documentation can also create an archive that can trace the history of the school and happiness in the process of learning experiences of the children with the teacher.

\section{Parents as partners.}

Participation of parents is very important. They could do a different role. Parents can take an active part in their children's learning experience and help ensure the well-being of all children in school. Ideas and skills that brought the family at school and, most importantly, a new way of educating, which helps teachers to look at family participation not as a threat but as an intrinsic element of friendship and as the integration of different policies.

The safety and comfort of our children is the most important element for our children in school; therefore, it is essential that the requirements of early childhood education teachers incorporating teacher's competence that dealing with problems concerning the safety and security of children. For example, their ability to provide first aid to children should be one of the main requirements to become early childhood teachers. The health early childhood teachers must also be considered in order not to disrupt the learning activities and not to infect the children under their supervision.

\section{H. Conclusion}

Considering the importance of children character building of children from an early age, it is proper if the recruitment of teachers also require competency testing for 3 to 6 months to demonstrate all of the competencies required. Competence can not only be assessed with a piece of paper called a diploma, but it must be tested and demonstrated and evaluated by the certified assessor before one is accepted and given full confidence to carry out this noble task to shape the character of Indonesian people who are able to live, socialize, and compete honestly and with dignity in a global society.

Our children are lucky to live in Indonesia where the character building is supported with the value of religion they acquire from their parents and family. This means that, Indonesian children will be able to 
grow up having a strong character which based on moral and religious value, something that is missing from the character building in most of developed countries.

To close this paper, there are two important recommendations to be made. First, improving the quality of the educational institution for early childhood education teachers, and second, improving the quality of early childhood teacher recruitment process.

Improving the quality of early childhood education should be started by improving the quality of early childhood education provider institutions. 


\section{REFERENCE}

Cadwell, L.B. (1997). Bringing Reggio Emilia home. New York: Teachers College Press

California Department of Education \& First 5 California. (2011). California early childhood educators competencies. Sacramento: CDE Publications and Resources.

OU CDC. (2011). Parent handbook. Athens: Ohio University.

Edward, C., Gandini, L., and Forman, G. (1993). The hundred language of children: The Reggio Emilia approach to early childhood education. USA: Ablex Publishing.

Gandini, L. (1993). Fundamentals of the Reggio Approach to Early Childhood Education. Young Children, 49 (1), 4-8.

Lewin, A. (1995). The Fundamentals of the Reggio Approach. In Cadwell, L. (Ed.). Bringing Reggio Emilia Home. New York: Teachers College Press.

Lynch, R. G. (2005). Early childhood investments yields big payoff (Policy Perspectives). San Francisco: WestED.

Malaguzzi, L. (1993). For an Education Based on Relationships. Young Children, 49 (1), 9-12.

Prensky, M. (2001). Digital-based game learning. New York: McGrawHill

Samuelsson, I. P and Kaga, Y. (2008). The contribution of early childhood education in sustainable development. Paris: UNESCO.

Sujiono, Y. N. (2009). Konsep dasar pendidikan anak usia dini. Jakarta: Indeks.

Wagiran. (2011). Peran guru dalam mengembangkan karakter pada pendidikan kejuruan di era global. Makalah.

Waller, C. (2011). Personal Communication. Athens: Ohio University 